\title{
POESIA, RESISTÊNCIA E ESPERANÇA EM CONCEIÇÃO EVARISTO
}

\section{POETRY, RESISTANCE AND HOPE IN CONCEIÇÃO EVARISTO}

\author{
Marcelo Medeiros da Silva* \\ Josivânia da Cruz Vilela**
}

\begin{abstract}
RESUMO: O presente artigo volta-se para o estudo da poesia de Conceição Evaristo. Para tanto, tem como corpus o livro Poemas da recordação e outros movimentos (2017). Objetiva-se ler tal obra a partir da categoria "esperança", no sentido emprestado a ela por Paulo Freire em Pedagogia da Esperança (2000), e da concepção de resistência, como concebida por Alfredo Bosi (2000) em O ser e o tempo da poesia. No cômputo geral, a esperança aparece na lírica de Conceição Evaristo revestida de um viés político, que se traduz como potência de resistência, e que visa à transformação das estruturas hegemônicas de poder que têm perpetuado injustiças sociais, discriminações e violências e, consequentemente, objetiva a construção de um futuro de liberdade e de igualdade que passa necessariamente pelo esperançar de Paulo Freire e pela resistência tal como assinalada por Alfredo Bosi.

Palavras-chave: Conceição Evaristo. Paulo Freire. Poesia. Esperança. Resistência.
\end{abstract}

ABSTRACT: This present paper pretends to Studi of the poetry Conceição Evaristo's in the title "Poemas da recordação e outros movimentos" (2017). The objective is to read such work from the categories "hope" (FREIRE, 2000) and "resistance" (BOSI, 2000) that appear in the lyrical of Conceição Evaristo with a political bias that aims at the tranformation of the hegemonic structures what has perpetuated social injustices, discrimination and violence and, consequently, building a future of freedom and equality that crises throug Freirian hope and for the resistance as signalizef by Bosi (2000).

Keywords: Conceição Evaristo. Paulo Freire. Poetry. Hope. Resistance.

\section{Introdução}

Maria da Conceição Evaristo de Brito nasceu em Belo Horizonte em 1946. De origem humilde, foi a primeira de sua família a obter diploma de curso superior. Graduada em Letras, é mestra em Literatura Brasileira e doutora em Literatura Comparada, tendo estudado sempre a produção literária afro-brasileira e suas relações com a literatura africana de língua portuguesa. Ela poderia ter sido a nossa primeira escritora negra na Academia Brasileira de Letras ( $\mathrm{ABL}$ ) se não fosse o reacionarismo que grassa na casa de Machado de Assis desde as suas origens, já que, durante muito tempo, negou às mulheres assento em uma de suas 40 cadeiras.

No verbete que lhe dedicam na antologia Literatura e afrodescendência no Brasil, Maria Consuelo Cunha Campos e Eduardo de Assis Duarte pontuam que a mesma coerência que se percebe na pesquisadora e em seus objetos de estudo é perceptível na professora Conceição Evaristo e em sua atuação no magistério que sempre levou em conta as questões étnicas:

\footnotetext{
* Professor do Centro de Ciências Humanas e Exatas da Universidade Estadual da Paraíba e membro do Programa de Pós-Graduação em Formação de Professores.E-mail: marcelomedeiros_silva@yahoo.com.br ** Graduada em Letras - Língua Espanhola pela Universidade Estadual da Paraíba. Foi, durante quatro anos, bolsista de Iniciação Científica com pesquisas voltadas para o estudo das relações entre mulher $\mathrm{e}$ literatura. E-mail: josivaniacruzvilela@gmail.com
} 
Iniciou sua militância pelo movimento operário e, a partir das discussões sobre classes sociais e o universo do trabalho, chegou às reivindicações étnicas e de gênero. Toda a sua atuação acadêmica, pesquisa e criação literária são profundamente marcadas por sua condição de mulher negra na sociedade brasileira. (CAMPOS e DUARTE, 2011, p. 208).

Como têm pontuado alguns estudiosos, Conceição Evaristo se insere em uma tradição da narrativa afro-brasileira de autoria feminina, que, historicamente, remonta à figura de Maria Firmina dos Reis, autora de Úrsula (1859), primeiro romance afrobrasileiro, e conta com nomes notáveis como os de Ruth Guimarães, Carolina Maria de Jesus, Esmeralda Ribeiro, Alzira Rufino, Ana Maria Gonçalves, Eliana Cruz.

A escritora tem, desde as suas origens, construído uma obra marcada pela forma poética com que, segundo Maria Consuelo Cunha Campos e Eduardo de Assis Duarte (2011, p. 208), "representa a crueldade do cotidiano dos excluídos. A mescla de violência e sentimento, de realismo cru e ternura, revela o compromisso e a identificação da intelectual afrodescendente com os irmãos colocados à margem do desenvolvimento". Escrita e vivência estão, portanto, profundamente imbricadas em Conceição Evaristo, tanto que ao amálgama entre as duas a escritora chamou de escrevivência. Sobre este aspecto, Campos e Duarte (2011) afirmam:

Com sua escrevivência - termo com que costuma demarcar sua produção -, Conceição Evaristo articula seus projetos literário e existência: a uma longa e persistente militância social, étnica e de gênero agrega-se a atuação acadêmica e a criação poética e narrativa. Põe em cena, sob uma perspectiva feminina a afro-identificada, problemas do cotidiano de mulheres negras, conectando sua literatura à raízes étnicas. Centrados na temática afro-brasileira, seus escritos consubstanciam sua resistência ao sexismo, ao racismo e aso demais preconceitos e formas correlatas de exclusão. Mas sem perder a ternura jamais (CAMPOS e DUARTE, 2011, p. 213).

Do conjunto de sua obra que conta com livros como Ponciá Vicêncio (2003), que "reúne as condições de ser o primeiro best-seller do romance afro-brasileiro" (CAMPOS e DUARTE, 2011, p. 213), Becos da Memória (2006), Insubmissas lágrimas de mulheres (2011), Olhos d'água(2014), Histórias de leves enganos e parecenças(2016), Canção para ninar menino grande(2018), vamos nos deter em alguns poemas do livro Poemas da recordação e outros movimentos(2008), obra que está dividida em seis partes precedidas por trechos em prosa que, à moda de epígrafes, trazem marcas do lirismo que perpassa toda a produção de Conceição Evaristo.

Nessa obra, deparamo-nos com versos que nos educam para a esperança no sentido freiriano do termo, isto é, não para a esperança estática que vem do verbo "esperar", mas, sim, a esperança que nos impele à participação, à luta e que vem do verbo "esperançar". Nesse sentido, como lembra Cortella, dentro do pensamento freiriano, "Esperançar é se levantar, esperançar é ir atrás, esperançar é construir, esperançar é não desistir! Esperançar é levar adiante, esperançar é juntar-se com outros para fazer de outro modo" (CORTELLA, 2001).

A presença da esperança como fio que costura os textos de Poemas de recordação e outros movimentos (2017) não é um gesto impensado ou inconsciente. Talvez, seja até mesmo um dos alicerces do projeto político e literário da escritora. Não 
à toa a categoria "esperança" fez parte da tese que ela escreveu e em que estuda a obra de Agostino Neto, poeta angolano, e Ney Lopes e Edimilson Almeida Pereira, poetas afro-brasileiros. Já na introdução da tese, Conceição Evaristo registra:

A palavra poética é um modo de narração do mundo. Não só de narração, mas, antes de tudo, a revelação do utópico desejo de construir outro mundo. Pela palavra poética, inscreve-se, então, o que o mundo poderia ser. E, ao almejar um mundo outro, a poesia revela o seu descontentamento com uma ordem previamente estabelecida (EVARISTO, 2011, p. 09).

Embora as palavras acima sejam da Conceição Evaristo, crítica literária, e tenham sido ditas acercada produção lírica dos poetas Agostinho Neto, Ney Lopes e Edimilson Almeida Pereira, acreditamos que essas palavras dizem muito da poética da própria Conceição Evaristo, poeta, e de sua participação como mulher negra na sociedade brasileira e de sua luta contra as desigualdades sociais. Por isso, como mostraremos na seção a seguir, em Poemas da recordação e outros movimentos (2017), a escritora constrói versos de esperança e, portanto, entoa um canto de utopia porque o futuro que se delineia a partir da leitura de cada um dos poemas que compõem a referida obra não é pura repetição do presente. A poesia de Conceição Evaristo resiste e, assim, o faz porque, como lembra o professor Alfredo Bosi, "A poesia resiste à falsa ordem, que é, a rigor, barbárie e caos. Resiste ao contínuo 'harmonioso' pelo descontínuo gritante; resiste aferrando-se à memória viva do passado; e resiste imaginando uma nova ordem que se recorta no horizonte da utopia" (BOSI, 2000, p.169), registrando, em rimas de sangue e fome, a voz dos oprimidos.

Em outras palavras, como mostraremos na seção a seguir, a resistência na poesia de Conceição Evaristo se constrói, ideologicamente, não apenas a partir da revisão do nosso passado histórico a fim de ver, sob uma outra óptica, a dos oprimidos, a narrativa que foi oficializada sobre tal passado, mas, também, da denúncia do presente, ainda marcado por injustiças e desigualdades, e, sobretudo, da anunciação de um futuro que poderá ser construído por homens e mulheres a partir da luta por transformação social. Por esse aspecto de anunciação do futuro, é que, a nosso ver, a poesia de Conceição Evaristo, mantém diálogo estreito com o pensamento de Paulo Freire acerca da esperança como motor da história.

Assim como inédito viável, utopia, sonho, a esperança é uma categoria-chave no pensamento de Paulo Freire e já se faz presente desde Pedagogia do Oprimido (1981), obra em que aparece como condição imprescindível para o diálogo, já que este não tem como existir em solo fertilizado pela desesperança (STRECK, 2010). A esperança é o eixo de Pedagogia da Esperança (1992), obra publicada em um período marcado por "avanços democráticos e por uma desilusão com utopias", mas, ao mesmo tempo, por aberturas para a participação popular e a implementação de políticas públicas inovadoras, como o Orçamento Participativo em Porto Alegre (STRECK, 2010, 270).

Como deixa claro na abertura da obra, Paulo Freire concebe a esperança como uma "necessidade ontológica", um "imperativo excepcional e histórico" (FREIRE, 2000 , p.14). Por isso, ela deve revelar-se na prática, não se confundir com imobilidade ou paralisia, uma vez que, assentada na ação, a esperança "impede tanto a acomodação pragmática à realidade quanto a fuga para idealismos incapazes de interferir na história". Sendo seres de esperança, homens e mulheres estão "diante da possibilidade de criar outro futuro" (STRECK, 2010, 271). 
Ora, se, para Freire (2000), a esperança é o anúncio de um futuro a ser criado, nos escritos de Conceição Evaristo esse anúncio vem através da palavra poética. Como poderemos perceber em Poemas da recordação e outros movimentos (2017), a construção desse futuro passa necessariamente pelo questionamento do passado e também do presente, uma vez que se faz necessário uma revisão crítica da história que não se centralize nos discursos já amplamente difundidos pelas culturas hegemônicas. Nesse sentido, a esperança freiriana que impulsiona a agir, sem nos imobilizar na espera, se configura como um imperativo existencial nos poemas da poeta em questão. Fazendo-se e refazendo-se através da escrita, Conceição Evaristo re/cria a história de tantos outros sujeitos marginalizados ao longo dos séculos, e o faz seja por meio de recordações, quando vêm à luz as marcas do cerceamento ao qual a população negra foi submetida, seja por meio de projeções do pensamento, quando se aponta para um possível tempo de liberdade e igualdade que se dará no futuro a ser construído na luta que se trava no presente.

Entre o passado de opressão e o futuro de possível liberdade, encontra-se o presente, tempo marcado pelo signo da resistência nos escritos de Conceição Evaristo. Para pensar essa resistência e suas nuances nos escritos da poeta, valemo-nos, então, de Alfredo Bosi (2000), especificamente quando o crítico enfatiza a potência da linguagem poética como meio de resistir às mais ásperas situações a que uma população pode ser submetida. Dessa forma, como veremos na seção seguinte, por meio da esperança, como concebida por Freire em Pedagogia da Esperança (2000), atrelada à resistência, conforme pensada por Bosi em O ser e o tempo da poesia (2000), Conceição Evaristo constrói uma poesia entoando na sua voz o canto dos/as oprimidos/as, ao passo que aponta para a edificação de um novo mundo e de novas relações sociais.

\section{Versos de Resistência e Esperança: uma leitura de Poemas da recordação e outros movimentos}

Por meio de seus poemas, Conceição Evaristo tece uma escrevivência que traz à tona a "experiência" de vida da população afro-diaspórica desde sempre marginalizada e silenciada nos meandros sociais e literários, ambos marcados pelo signo da exclusão de sujeitos não pertencentes à elite econômica brasileira, ao padrão homem, branco, heterossexual. Como a própria poeta afirma, essa vivência se anuncia como sentido gerador na sua produção literária, como uma cadeia de sentidos na qual se fundamenta e inicia a sua dinâmica de resistência enquanto representante de uma classe social invisibilizada (DUARTE e NUNES, 2020).

Em $O$ ser e o tempo da poesia (2000), Bosi afirma que a resistência tem muitas faces: recuperação do sentido comunitário de um povo; crítica direta ou velada de uma ordem social estabelecida e tomada como natural; ou ainda, como melodia dos afetos no sentido mitológico. Como se poderá constatar mais amiúde a partir das análises dos poemas a seguir, Conceição Evaristo se utiliza dessas diversas facetas da resistência para expressar-se. No entanto, para entender esse ímpeto de luta que se inscreve nos escritos da poeta, é preciso levar em conta também o sentimento que impulsiona sua criação, ao menos no que concerne aos Poemas da recordação e outros movimentos (2017), que é precisamente a esperança em um futuro de igualdade e liberdade, o qual encontra eco em Pedagogia da Esperança (2000), de Paulo Freire. Dessa forma, ressaltamos que é precisamente tomando como base teórica principal os pressupostos de 
Freire (2000) e Bosi (2000), acerca de esperança e resistência, respectivamente, que elaboramos as análises dos poemas que seguem.

No poema a seguir, mais que mencionar seus/suas ancestrais, a poeta os/as evoca, provocando um aquilombamento ${ }^{1}$ (se quisermos utilizar o termo) que ultrapassa gerações, e se coloca na atualidade enquanto modo de resistência, e também como potência de transformação da realidade. Paulo Freire (2000) nomeia essa vontade de transformação da realidade justamente de esperança, aquilo que nos impulsiona a agir. Nesse sentido, ao rememorar a nossa história, que vem dos navios negreiros, a escritora não somente ultrapassa espaços/tempos, voltando ao passado, mas aponta para a construção de um futuro diferente que passa, necessariamente, pela esperança. Em consonância com Bosi (2000), poderíamos dizer que, na resistência que se materializa na página poética, o canto da escritora chama para si todos os tempos, de modo a evocar o passado, provocar o presente e invocar/convocar o futuro:

Todas as manhãs

Todas as manhãs acoito sonhos e acalento entre a unha e a carne uma agudíssima dor.

Todas as manhãs tenho os punhos sangrados e dormentes tal é a minha lida cavando, cavando torrões de terra, até lá, onde os homens enterram a esperança roubada de outros homens.

Todas as manhãs junto ao nascente dia Ouço a minha voz-banzo, âncora dos navios de nossa memória. E acredito, acredito sim que os nossos sonhos protegidos pelos lençóis da noite ao se abrirem um a um no varal de um novo tempo escorrem as lágrimas fertilizando toda a terra Onde negras sementes resistem reamanhecendo esperanças em nós.

(EVARISTO, 2017, p. 13)

Logo na primeira estrofe, vejamos que o eu-lírico afirma que "acoita sonhos", o que nos sugere que os acolhe. Nesse caso, o "acoitar sonhos" vem acompanhado de uma dor agudíssima "entre a unha e a carne". Ora, dor semelhante podemos sentir quando praticamos uma ação que exija uma fricção entre essas duas partes do dedo, como o ato da escrita, por exemplo. Nesse sentido, não seria errôneo conjecturar que o eu-lírico acoita tais sonhos através da escrita e o faz com tal frequência ("todas as manhãs") que

\footnotetext{
1 Termo utilizado por Conceição Evaristo, para falar da necessária união entre a população negra. Inclusive, união esta que ultrapassa gerações, ocorrendo não somente entre os vivos, mas destes com seus/suas ancestrais.
} 
chega a sentir as dores oriundas do ato que realiza porque a matéria sobre a qual escreve lhe é dolorosa, já que sua escrita é uma reescrita de um passado de violência, dor e opressão.

Aliás, como veremos na segunda estrofe, até os punhos do eu-lírico se encontram "sangrados e dormentes" de tanto cavar os torrões de terra, "onde os homens enterraram/ a esperança roubada de outros homens". Poderíamos ler esses versos como um canto contra o esquecimento de um povo que sempre foi marginalizado e espoliado de tudo, inclusive do direito de registrar a própria história. Nesse sentido, os torrões de terra que são persistentemente escavadas podem metaforizar a própria história, que cobre tais sujeitos sob densas camadas de esquecimento, apagando-os literalmente de registros e demais documentos, como se nunca houvessem existido. Junto a esses indivíduos que sequer são lembrados, vão-se também suas esperanças, tão enterradas quanto eles.

No entanto, mesmo sendo voluntariamente apagadas, essas vozes ressoam para o eu-lírico, de modo que "todas as manhãs ouço a minha voz-banzo" se unindo com outras vozes que anseiam por liberdade. Vale ressaltar que, nesse caso, essa/s voz/es se apresenta/m como "ancoras dos navios de nossa memória". Com esses versos, notemos dois pontos de suma importância. Primeiro, nesse contexto, o vocábulo "navios" nos remete ao tráfico negreiro durante o período da escravidão, o que pode ser confirmado pelo termo "banzo" que aparece no verso anterior e que aponta para a nostalgia/depressão que acometia a população negra que era trazida para o Brasil para servirem de escravos. Segundo, esses fatos parecem estar gravados na memória do eulírico. Por essa perspectiva, a instância poética parece recuperar do passado e da memória (BOSI, 2000) o que se enuncia no escrito. Afinal, como afirma Freire (2000, p. 16), "carregamos conosco a memória de muitas tramas, o corpo molhado de nossa história, de nossa cultura". Assim, poderíamos dizer que o poema recupera a trajetória de tantos sujeitos oprimidos no registro de sua voz. Em outros termos, o discurso presente nesse escrito traz à tona "o coro de todos que trabalhavam sob o ritmo da dominação" (BOSI, 2000, p. 178), enquanto ansiavam por liberdade.

Além disso, no poema acima, o eu-lírico se coloca integrado ao meio de toda uma população, já que afirma acreditar que "nossos sonhos/ protegidos pelos lençóis da noite" se abrirão. Mais do que isso, esses sonhos se abrirão em um novo tempo, o que evidencia que eles estão guardados esperando o momento propício para florescer e fertilizar "toda a terra/ onde negras sementes resistem/ reamanhecendo esperança em nós". Nesses versos, podemos perceber que essas sementes podem apontar para a população negra que resiste até hoje às discriminações e desigualdades que vigoram ainda hoje na sociedade. É justamente essa resistência banhada a sonhos que faz o eulírico sentir esperança, sentimento que nos impulsiona a refazer o mundo na luta dos/as oprimidos/as.

Em suma, no poema, por meio da resistência mesclada a "esperança, almas antes proibidas simplesmente de falar gritam e cantam, corpos proibidos de pensar discursam e arrebentam as amarras que os prendiam" (FREIRE, 2000, p. 90), como se o eu-lírico carregasse em si a voz e as vivências marcadas por interdições de todos os seus antepassados. Corroborando essa ideia, no poema a seguir, o sujeito do discurso traz para a zona do debate contemporâneo as vozes das mulheres que fizeram/fazem parte de sua vida e que foram sumariamente impedidas de emanar seus anseios, desejos, vozes:

Vozes-mulheres 


\author{
A voz da minha bisavó \\ ecoou criança \\ nos porões dos navios. \\ Ecoou lamentos \\ de uma infância perdida. \\ A voz da minha avó \\ ecoou obediência \\ aos brancos-donos de tudo. \\ A voz de minha mãe \\ ecoou baixinho revolta \\ no fundo das cozinhas alheias \\ debaixo das trouxas \\ roupagens sujas dos brancos \\ pelo caminho empoeirado \\ rumo à favela.
}

A minha voz ainda ecoa versos perplexos com rimas de sangue

e

fome.

A voz de minha filha

recorre todas as nossas vozes

recolhe em si

as vozes mudas caladas

engasgadas na garganta.

\section{A voz da minha filha}

recolhe em si

a fala e o ato.

O ontem - o hoje - o agora.

$\mathrm{Na}$ voz da minha filha

se fará ouvir a ressonância

$\mathrm{O}$ eco da vida-liberdade.

Valendo-se de trinta versos, distribuídos em seis estrofes, o eu-lírico percorre a trajetória de suas ancestrais através da palavra, de tal forma que "a carne do signo poético aparece quase em substância” (BOSI, 2000, p. 30). O que se tem é, pois, um novo modo de suplência da voz, no sentido em que Bosi (2000) utilizou o termo para falar de dicções que abrem caminho para que se dê uma nova presença dos seres, suprindo distâncias e ultrapassando o tempo dos sujeitos corpóreos.

Notemos que, na primeira estrofe, o eu-lírico afirma que "a voz de sua bisavó/ "ecoou criança/ nos porões do navio/Ecoou lamentos/ de uma infância perdida", o que nos evidencia que a infância de sua bisavó foi brutalmente roubada, trocada pelo trabalho escravo. Em realidade, foram roubadas a vida e a liberdade de sua avó quando ela foi deslocada de sua terra para, forçadamente, trabalhar em paragens desconhecidas. Filha de uma escravizada, como vemos na segunda estrofe, a avó do eu-lírico teria o 
mesmo "destino" de opressão, tendo que obedecer aos "brancos-donos de tudo" para não morrer. Nesse caso, obedecer é uma estratégia para continuar sobrevivendo, mesmo que esse viver não diferisse muito da morte; afinal, o indivíduo na "condição" de escravo estava sepultado para o mundo.

Já na terceira estrofe, há uma primeira mudança de "status" social referente às mulheres que fazem parte da família do sujeito do discurso poético. Ora, a mãe do eulírico não é escravizada, embora "continue no fundo das cozinhas alheias", lavando "roupa dos brancos". Mesmo que não se configure como escravo, o trabalho mal remunerado, porém, reproduz a mesma lógica de exploração, injustiça social e desigualdade de que, no passado, foram vítimas os escravizados e no presente permanecem sendo vítimas os seus descendentes.

Outro ponto interessante é que o eu-lírico deixa sugerido que sua mãe morava na favela, justamente os espaços sem saneamento básico, em condições precárias, afastados do centro das cidades, para onde os escravizados foram empurrados quando do momento da alforria. No entanto, o curioso é que nesse momento já ecoa, ainda que baixinho, a revolta sentida pela mãe do sujeito lírico, o que aponta para o começo de uma reviravolta na trajetória familiar e para a libertação das amarras a que estava submetida. Essa libertação se acentua consideravelmente a partir do eu-lírico que já ecoa sua voz através de seus poemas, mesmo que suas rimas estejam marcadas por sangue e fome, signos de uma luta contra os preconceitos sociais e contra as próprias necessidades decorrentes das injustiças históricas que marcam a sua trajetória e a de suas ancestrais.

$\mathrm{Na}$ quinta estrofe, a filha do eu-lírico já carrega em si todas as vozes que foram caladas, inclusive as que não saíram da garganta e ficaram embargadas entre o dizer e o morrer. Para além da voz, ela recolhe o ato, algo que a impulsiona a agir, recolhe também "o ontem - o hoje - o agora" e "é nessa altura que se defrontam os tempos: o tempo corpóreo, e o tempo 'quebrado' de histórias socais" (BOSI, 2000, p. 111) marcadas por dores e sofrimentos, mas também ungidas de resistência e esperança; esperança que chegue um tempo em que as pessoas negras não sejam mortas devido a sua cor. É esse sentimento de confiança no porvir que faz o eu-lírico afirmar que na voz de sua filha "se fará ouvir a ressonância/ o eco da vida-liberdade". Nas palavras de Alós (2011, p. 287): "Mais do que restaurar as heranças africanas através da construção de uma genealogia matrilinear, essa genealogia subverte o histórico de silêncio racista e patriarcal, ao mesmo tempo que assegura, no eco da vida-liberdade da última mulher negra mencionada no poema, uma afirmação de resistência e de espaço conquistado".

Dessa forma, poderíamos dizer que, em duplo movimento, o eu-lírico para além de resgatar suas origens ancestrais, aponta para um processo gradativo de libertação, que é conseguido justamente a partir da resistência de suas antepassadas. Nesse sentido, se a filha do sujeito que enuncia no poema consegue emanar o eco da vida-liberdade é, também, devido à luta de suas ancestrais. Ainda nos valendo de Alós (2011, p. 286), podemos afirmar que, nesse poema, como alternativa para enfrentar esse silêncio secular, o eu-lírico "realiza uma arqueologia afetiva, escavando nas memórias familiares elementos que permitam ao sujeito poético afirmar-se no mundo, ao mesmo tempo que reconstitui as suas origens e concretiza sua identidade" marcada por lutas e impedimentos de toda ordem.

Em outros termos, fazendo-se e refazendo-se a partir da escrita que traz, imiscuídas, vozes/presenças de outras vozes ancestrais, o sujeito do discurso poético vê, na semente que germinou de si mesmo - a própria filha - e que carrega diversas vozes silenciadas, o sonho de uma vida livre e de uma outra história possível. Se, como afirma 
Freire (2000), o sonho também se configura como o motor da história, então não há mudança sem sonho tampouco há sonhos sem esperança. Aliás, um povo não pode viver sem esperança, sem os sonhos (HALL, 2003). É precisamente esse sonho que se converte em realidade o que veremos no próximo poema:

\author{
Para a menina \\ Desmancho as tranças da menina \\ e os dedos tremem \\ medos no caminho \\ repartidos de seus cabelos. \\ Lavo o corpo da menina \\ e as minhas mãos tropeçam \\ dores nas marcas-lembranças \\ de um chicote traiçoeiro.
Visto a menina
e aos meus olhos
a cor de sua veste
insiste e se confunde
com o sangue que escorre
do corpo-solo de um povo.
Sonho os dias da menina
e a vida surge grata
descruzando as tranças
e a veste surge farta
justa e definida
e o sangue se estanca
passeando tranquilo
na veia de novos caminhos, esperança.

para as meninas e meninos de cabelos trançados ou sem trança

(EVARISTO, 2017, p. 36)

Nesse poema, o corpo da menina se configura quase à maneira de capas que se despregam ao passo que o eu-lírico o toca; como palimpsesto no qual se gravaram tantas histórias passadas, mas que, se olhadas com o devido cuidado, aparecem simultâneas, ao menos enquanto escritura/lembrança. Nesse sentido, as mãos do sujeito do discurso obedecem a um impulso constante de perceber a dinâmica da substância (BOSI, 2000) de que se constitui essa "menina".

Na primeira estrofe, percebamos que, enquanto desmancha as tranças da menina, o eu-lírico se treme ao percorrer os caminhos dos seus cabelos que no poema pode nos fazer lembrar os trajetos minados que tiveram de percorrer os negros em busca de sua liberdade. Em tempos de escravatura, essa mínima liberdade se concentrava nos quilombos, mas até chegar a esses locais muitos eram os obstáculos, tantos que diversos escravizados, embora fugidos, nem sequer chegavam a esses lugares de acolhimento e resistência. Já na segunda estrofe, vemos que, enquanto o eu-lírico lava o corpo da 
menina, suas mãos sentem as dores mescladas com lembranças dos chicotes que feriam não somente o corpo, mas também a alma de diversos seres humanos. Aliás, embora cada sensação venha após tocar uma parte do corpo da "menina", nos parece que não é no corpo desse sujeito onde se incidem tais dores, mas, sim, no corpo/lembrança do eulírico.

Dessa forma, o que o corpo da menina involuntariamente faz é ativar essas lembranças/dores que ainda não foram cicatrizadas, posto que profundas. Justamente por isso, na terceira estrofe, ao vestir a menina, o eu-lírico tem a impressão de ver o sangue de todo um "corpo-solo" sendo derramado. Ora, ao utilizar o termo "corpo-solo" o sujeito do discurso aponta para dois pontos. Primeiro, o solo é o local onde pisamos constantemente, o que nesse escrito pode sinalizar para o quão expropriado foi o corpo desse povo. Segundo, o solo é algo que aponta para a sustentação, é a base, de onde germina a vida. Assim, unindo as duas perspectivas, esse corpo de que fala o eu-lírico, ainda que macerado, se configura como elemento vital porque serve como ponto de apoio, mas também de nascimento, de renovação, uma vez que, por mais que seja expropriado, esse corpo-solo não deixa de ser fértil e, por isso, resiste como campo de lutas, revoltas e esperanças.

Novamente, o "destino" da menina começa a mudar quando o eu-lírico imagina outras possibilidades de existência. Na quarta estrofe, quando começa a sonhar com "os dias da menina,/ a vida surge grata", como se todos os percalços pelos quais o sujeito do discurso, assim como tantas outras pessoas, passou tenham possibilitado o ressurgir de dias melhores. Por essa perspectiva, a luta, mesmo que por vezes travada em silêncio, mas em um silêncio que fala mais do que palavras, possibilita novos rumos. Nesse caso, o sonho de que fala o poema não é letargia. É impulso a agir, é potência, é força, anseio por transformação, por combate às injustiças.

Então, quando se descruzam as tranças, e a veste surge farta e definida, o sangue se estanca e volta a passear nas veias, trilhando novos caminhos. Dessa vez, pelos prumos da Esperança. Em outros termos, quando liberta das amarras sociais, a vida toma os rumos naturais, o sangue deixa de escorrer pelos corpos feridos, machucados, para vibrar nas veias, potenciando dias de esperança. Corroborando as ideias de Bosi (2000, p. 141), podemos enfatizar que esse poema se configura como "uma longa estrada que percorre as voltas da memória e os labirintos do inconsciente", de modo a surgir na página com potência de transformação e conscientização social. Se pensamos a partir da perspectiva de Freire (2000), podemos dizer também que o sujeito do discurso inventou a esperança concreta, que se materializa, nesse caso, através da escrita poética. É nessa luta por libertação que se alça no horizonte o nome Abdias do Nascimento no poema que comentamos abaixo:

Dias de Kizomba

$$
\begin{gathered}
\text { Ab(dias) de lutas e não de luto. } \\
\text { Um homem como Abdias, } \\
\text { estrela incandescente, } \\
\text { não morre. } \\
\text { A sua luz, } \\
\text { cor negra zagaia } \\
\text { feriu a branca consciência } \\
\text { de uma democracia racial } \\
\text { nula e vil. }
\end{gathered}
$$




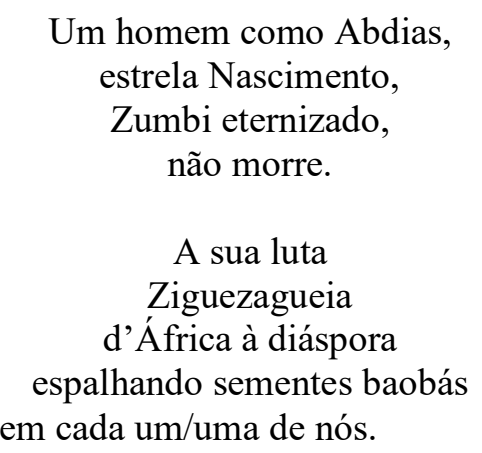

(EVARISTO, 2017, p. 57)

Como afirma Bernd (2011), Abdias do Nascimento é um dos mais destacados ativistas do século XX. Ele foi ator, diretor, dramaturgo e professor, além de militante da luta contra a discriminação racial e pela valorização da cultura negra. No caso da militância, o ativista começa com suas ações de combate à discriminação racial em 1930, quando integra a Frente Negra Brasileira. Durante sua trajetória, além de ter comandado o jornal Quilombo, fundou o TEN - Teatro Experimental do Negro - e organizou diversos congressos, entre eles a "Conferência Nacional do Negro" (1949), e escreveu peças teatrais, como "Rapsódia Negra" (1952), todas essas ações levando em consideração questões de interesse da população negra/afro-descente. Devido a seus feitos de combate ao preconceito, ficou exilado durante treze anos, mas continuou com suas lutas mesmo fora do Brasil.

Considerando essa breve apresentação sobre Abdias do Nascimento, notemos que, logo no primeiro verso do poema acima, o eu-lírico, jogando com as palavras, utiliza o termo "Ab(dias)", que, se por um lado sinaliza para o nome do ativista em quem o poema se detém, por outro pode nos levar a ler o "ab" a partir de seu significado como prefixo latino, sinalizando, pois, para afastamento, separação. Nesse sentido, podemos perceber que esse verso aponta para os dias de ausência do militante, já falecido. No entanto, o interessante é que, mesmo Abdias do Nascimento não estando vivo, também não se nutre um sentimento de luto, mas há um impulso para a luta. $\mathrm{Na}$ realidade, como vemos ainda na primeira estrofe, "um homem como Abdias/ estrela incandescente/ não morre", ou seja, como um astro de luz, permanece a guiar as pessoas, eternizando-se e fazendo-se presente ainda que de forma longínqua. Transformando-se em luz que irradia, Abdias não pode ser tocado, mas não há dúvida de que o eu-lírico sente a sua presença; aliás, todo o escrito está permeado por essa atmosfera luminosa. Nesse poema, o que faz o sujeito do discurso é, então, "suprir a ausência de uma pessoa, chamando-a, exprimindo o sentimento que ela provoca, essa é a direção fundamental da linguagem (BOSI, 2000, p. 53) que se espraia nos versos até o fim do escrito.

Outro ponto que vale ressaltar é que a cor da luz que vem de Abdias é negra, assim como ele o era quando vivo. Para além disso, como uma lança, essa luz zagaia "feriu a branca consciência/ de uma democracia racial/ nula e vil". Nesses versos, percebamos que o eu-lírico denuncia a falsa concepção de que temos uma democracia racial, ao passo que também aponta para o quanto importante foi/é a figura e o legado de Abdias do Nascimento para a conscientização acerca dos preconceitos que ainda são cultivados socialmente, mesmo que de forma velada. Em um meio social onde se insiste em negar a existência do racismo e se prega o equivocado mito da democracia racial, o 
militante em questão realmente feriu a consciência de muitas pessoas intolerantes e preconceituosas, ao lutar pelos direitos dos indivíduos negros.

É precisamente por sua luta incessantemente que, na terceira estrofe, Abdias do Nascimento é igualado a Zumbi dos Palmares, um que é dos mais importantes representantes da resistência das pessoas negras à escravidão durante o período escravocrata no Brasil e que também é uma figura eternizada, iluminada, "não morre". Mas, caso ainda não tenho sido notado, poderíamos nos perguntar o que faz de Abdias do Nascimento, assim como Zumbi dos Palmares, perdurar aos séculos?! A resposta pode ser encontrada na quarta e última estrofe do poema acima: "a sua luta/ ziguezagueia/ d'África à diáspora: espalhando sementes baobás/ em cada um/uma de nós". Em outros termos, além do legado que esse ativista nos deixou e que é fruto de todas as suas ações em prol da população negra, não só do Brasil, mas de outros países também, a sua luta ainda se faz necessária e reverbera em cada um de nós, sejamos negros ou brancos, mas que tenhamos consciência do quão prejudiciais são o racismo, a discriminação. Como a árvore africana que vive muitos anos e possui tronco firme ao solo, as sementes baobás que Abdias do Nascimento nos deixa frutificam resistência e esperança. Isto é, o seu legado não feneceu quando ele morreu. Como ideia, luta, resistência, Abdias Nascimento permanece vivo e suas palavras renascem em cada um de nós comprometidos com a transformação dessa sociedade ainda injusta, desigual e discriminatória.

Nesse sentido, podemos dizer que, nos poemas de Conceição Evaristo, “a palavra expectante desencadeia uma imagem de futuro em que todas as pessoas desfrutarão da liberdade" (BOSI, 2000, p. 181). Talvez esses anseios por liberdade e igualdade pareçam um pouco utópicos; para nós se configuram como uma atitude ética. E se fosse utopia, e "estas não se alcançassem porque sempre haverá outra mais distante, não importa: caminhemos na sua direção - assim é a vida, melhor do que ficar parado, passivos (BOAL, 2009, p. 34). Além disso, como afirma Freire (2000), a utopia não seria possível se faltasse a ela o gosto pela liberdade, embutido na vocação para a humanização. Se faltasse, pois, a esperança, sem a qual não lutamos por dias melhores, não seria possível prevalecer igualdade e liberdade. É exatamente esse gosto pela liberdade que reverbera nos poemas de Conceição Evaristo e do qual somente trouxemos uma amostra.

Enfim, podemos afirmar que a produção literária da escritora pulsa, como se fosse construída com fios de esperança, trabalhada minuciosamente no tecido da resistência. Para nos valer de metáfora semelhante à utilizada pela própria Conceição Evaristo, poderíamos enfatizar que seus poemas são sementes que, espalhadas pelo mundo, têm potência para frutificar em cada ser humano, seja homem ou mulher, seja branco ou negro, mas para isso é necessário terra fértil, ou seja, devemos estar abertos/as a visões outras de mundo que não se enquadram em ideologias dominantes, marcadas pelo signo da exclusão.

Dessa forma, unindo tanto o estético quanto o político, através da escrita de poemas, Conceição Evaristo empreende um movimento de absorção, análise e questionamento do tempo passado e presente, criando um espaço de contestação do mundo que a rodeia; isso porque a linguagem nos possibilita construir percepções acerca da realidade que nos constitui como seres humanos. Em outras palavras, a partir da linguagem poética, a escritora testemunha não apenas a condição a que está impelida, mas revela a dinâmica social que envolve o ser e estar no mundo na condição de mulher negra, sujeito duplamente marginalizado. 


\section{Considerações finais}

Pelos labirintos da memória, com suas lembranças navegáveis, a poesia de Conceição Evaristo, sem desconsiderar as razões históricas, econômicas e socias que lhe servem de esteio, trava uma luta contra o silêncio, as injustiças. Como essa luta ainda não cessou, essa mesma poesia, sem desconsiderar o passado, mas também sem se descurar do presente, vislumbra um futuro nascido do sonho e da esperança. Um futuro que, por não desconsiderar o chão que o alimentou, se desenha como a utopia de um mundo diferente do que tivemos e temos, um futuro de congraçamento entre os povos.

Nesse sentido, valendo-nos de Paulo Freire, podemos dizer que os versos de Conceição Evaristo são esperançosos em virtude de um "imperativo existencial e histórico" (FREIRE, 2000, p.14). Não são versos de uma esperança ingênua. São versos que sabem os dados concretos e materiais que impulsionam a luta de que participam a fim de transformar as condições concretas que fomentam as desigualdades, as injustiças, as opressões.

A voz lírica da poesia de Conceição Evaristo sabe que, ainda que a esperança seja o alento da luta, ela, sozinha, não é o suficiente para transformar o mundo. Mais uma vez reportamo-nos a Paulo Freire quando afirma que "Sem um mínimo de esperança não podemos sequer começar o embate, a esperança, como necessidade ontológica, se desarvora, se desendereça e se torna desesperança que, às vezes, se alonga em trágico desespero" (FREIRE, 2000, p. 15). É preciso aliar esperança e luta. E as armas de Conceição são, justamente, seus versos, suas obras que nos põem diante de uma esperança que nasce da luta e dos sonhos de seus/suas ancestrais e que está comprometida com a revisão das formas como foi escrita a história que os grupos hegemônicos tentam legitimar como única.

Há na obra de Conceição Evaristo, portanto, a preocupação com uma coletividade cuja força pujante é minimizada nas fontes oficiais a partir das quais aprendemos a ler a história que foi escrita e a que muitos de nós fomos acostumados a ouvir como axioma. Nesse sentido, a poesia de Conceição Evaristo não é eco dessa coletividade, mas voz de vários sujeitos que, espoliados historicamente, encontra na escrita/verbo da autora espaço não só de memória, mas de permanência, luta e resistência.

No chão sulcado da opressão, os versos de Conceição advogam o direito dos oprimidos à esperança de ser e existir sendo quem são, sujeitos "em permanente processo de libertação" (FREIRE, 2000, p.60) para os quais, se o passado traz as marcas do trauma, o futuro não precisa ser assentando nesse mesmo alicerce. Os versos da poeta-romancista desenham uma possibilidade de futuro distinto do que foi o passado de opressão e desigualdades. Parafraseando Freire (2000), podemos dizer que o discurso poético instaurado por Conceição Evaristo não é um discurso de adequação aos fatos como eles se deram no passado ou como reverberam no presente, mas de luta para que esses mesmos fatos possam dar-se de outra forma, de outra maneira.

Por tal perspectiva, é que vemos na poesia de Conceição Evaristo um diálogo com o pensamento de Paulo Freire no que tange à importância da esperança como motor da história, isto é, "A utopia, o inédito viável de que tanto fala, em todos os seus textos, o sonho possível não se realizará sem a denúncia da realidade injusta e o anúncio de um mundo melhor" (REDIN, p. 105). Na lírica da poeta, vemos a inscrição do sonho de 
transformação social e isso não é feito de forma ingênua porque, como ensina Paulo Freire (2000, p. 126):

Sonhar não é apenas um ato político necessário, mas também uma conotação da forma histórico-social de estar sendo mulheres e homens. Faz parte da natureza humana que, dentro da história, se acha em permanente processo de tornar-se.

Sendo o sonho o motor da história, "Não há mudança sem sonho, como não há sonho sem esperança" (FREIRE, 2000, p. 126). Por isso, é do interesse das classes dominantes que às classes dominadas não lhes seja facultado o direito de sonhar, já que, ainda segundo Freire (2000, p.127), "quanto menos [as classes dominadas] exercitarem a aprendizagem política de comprometer-se com uma utopia, quanto mais se tornarem abertas aos discursos 'pragmáticos', tanto melhor dormirão as classes dominantes" (FREIRE, 2000, p. 127). A nosso ver, esse pensamento de Paulo Freire reverbera no agir poético e político de Conceição Evaristo quando a escritora afirma: "Nós não escrevemos para adormecer os da casa-grande, pelo contrário, é para acordá-los dos seus sonos injustos". Aqui, ela demarca a sua posição política como escritora e enuncia a sua utopia. Afinal, reportando-nos mais uma vez a Freire: "O sonho é assim uma exigência ou uma condição que se vem fazendo permanente na história que fazemos e que nos faz e refaz" (FREIRE, 2000, p. 137).

Sonhar é, pois, uma forma política de recriar o mundo e, assim como Freire fez, Conceição Evaristo segue, a seu modo, "sonhando o sonho possível de mudar o mundo", o que a faz uma "profeta de um novo mundo", de acordo com Jurema Verneck, em seminário recentemente realizado sobre a obra Conceição Evaristo e promovido pelo Itaú Social $^{2}$. Um novo mundo que, a nosso ver, se ergue sob o diáfano manto da Esperança que, presença viva, se espraia em cada texto que Conceição Evaristo traz à luz porque, como afirma a própria escritora em sua tese de doutorado, "a palavra com o seu valor performático é a potência que rege o mundo. A palavra tem a força de fazer acontecer, sendo premonitória, inclusive" (EVARISTO, 2011, p. 09). Esse modo de valorização e de entendimento da força do dizer, da potência da palavra que Conceição investiga nos autores que estudou em sua tese também se encontra presente na poesia que ela própria escreve e de que nos serve como exemplo o conjunto de poemas do livro "Poemas da recordação e outros movimentos". Parafraseando o pensamento do professor Alfredo Bosi, podemos dizer que a poesia de Conceição Evaristo, "sob as espécies da figura e do som, traz aquela realidade pela qual, ou contra a qual, vale a pena lutar" (BOSI, 2000, p. 227). Logo, é uma poesia de resistência, mas também de esperança.

\footnotetext{
2 Trata-se do seminário "A escrevivência de Conceição Evaristo" que, promovido pelo Itaú Social, ocorreu entre os dias 11 e 12 de novembro de 2020, via canal do youtube, contou com a participação da própria escritora e de alguns pesquisadores e pesquisadoras que debateram sobre o conceito de escrevivência cunhado pela própria Conceição Evaristo quando da escrita de sua dissertação de mestrado em 1996. Ao final dos debates, foi lançado o livro que norteou as discussões: Escrevivência: a Escrita de Nós - Reflexões sobre a Obra de Conceição Evaristo.
} 


\section{Referências}

ALÓS, Anselmo Perez. O lirismo dissonante de uma afro-brasileira. Estudos Feministas. Florianópolis jan-abril 2011. p. 286-288.

BERND, Zilá (org.). Antologia de poesia afro-brasileira: 150 anos de consciência negra no Brasil. Belo Horizonte: Mazza, 2011.

BOAL, Augusto. A Estética do Oprimido. Rio de Janeiro: Garamond. 2009.

BOSI, Alfredo. O ser e tempo da poesia. São Paulo: Companhia das Letras. 2000.

CORTEllA, Mário Sérgio. A resignação como cumplicidade. Folha de São Paulo, São Paulo. 08 nov. 2001. Disponível em: https://www1.folha.uol.com.br/fsp/equilibrio/eq0811200123.htm. Acesso em: 20 nov. 2020.

CAMPOS, Maria Consuelo Cunha; DUARTE. Eduardo de Assis. Conceição Evaristo. In: DUARTE, Eduardo de Assis (Org.). Literatura e Afrodescendência no Brasil: antologia crítica. vol. 2. Belo Horizonte: UFMG, 2011, p. 207-225.

DUARTE, Constância Lima; NUNES, Isabella Rosado. Escrevivência: a escrita de nós: reflexões sobre a obra de Conceição Evaristo. Rio de Janeiro: Mina Comunicação e Arte. 2020.

EVARISTO, Conceição. Poemas da recordação e outros movimentos. 3. ed. Rio de janeiro: Malê, 2017.

EVARISTO, Conceição. Poemas malungos - cânticos irmãos. Tese (Doutorado em Literatura Comparada). Instituto de Letras. Universidade Federal Fluminense. Rio de Janeiro, p. 172, 2011.

FREIRE, Paulo. Pedagogia da Esperança: um reencontro com a Pedagogia do Oprimido. São Paulo: Paz e Terra, 2000.

HALL, Stuart. Da diáspora: Identidades e mediações culturais. Belo Horizonte: Editora UFMG. 2003.

STRECK, Danilo R. Esperança. In: STRECK, Danilo R.; REDIN, Euclides; ZITKOSKI, Jaime José (Orgs.). Dicionário Paulo Freire. 2. ed. rev. e ampl. Belo Horizonte: Autêntica Editora, 2010, p. 270-271.

Recebido em 02 de novembro de 2020

Aceito em 20 de dezembro de 2020 